\title{
Breast Cancer cN0 TNM Finding v8
}

National Cancer Institute

\section{Source}

National Cancer Institute. Breast Cancer cNO TNM Finding v8. NCI Thesaurus. Code C139398.

Breast cancer with no regional lymph node metastases (by imaging or clinical examination). (from AJCC 8th Ed.) 